\title{
On the (Ir)Relevance of Distribution and Labor Supply Distortion to Government Policy
}

\section{Citation}

Louis Kaplow, On the (Ir)Relevance of Distribution and Labor Supply Distortion to Government Policy, 18 J. Econ. Persp. 4 (2004).

\section{Published Version}

http://www.jstor.org/stable/3216797

\section{Permanent link}

http://nrs.harvard.edu/urn-3:HUL.InstRepos:12187122

\section{Terms of Use}

This article was downloaded from Harvard University's DASH repository, and is made available under the terms and conditions applicable to Other Posted Material, as set forth at http:// nrs.harvard.edu/urn-3:HUL.InstRepos:dash.current.terms-of-use\#LAA

\section{Share Your Story}

The Harvard community has made this article openly available.

Please share how this access benefits you. Submit a story.

Accessibility 


\title{
On the (Ir)Relevance of Distribution and Labor Supply Distortion to Government Policy
}

\author{
Louis Kaplow
}

$\mathbf{W}$

hen assessing government policies, economists are guided by certain basic principles. To determine the provision of public goods, economists use cost-benefit analysis: A public good should be provided if, and to the degree that, its benefits- the sum of all individuals' benefits- exceed its costs, in accordance with what is known as the "Samuelson rule." To solve problems involving negative externalities, economists favor internalization: Actors should be made to bear the full social costs of their decisions, such as by imposing taxes equal to the marginal external cost of their activities—-Pigouvian taxation."

Two difficulties with these principles are often raised. First, distributive effects are implicitly ignored. But if a public good disproportionately favors the poor, should it perhaps be provided beyond the level at which the benefits otherwise justify its cost? Likewise, if a gasoline tax is regressive, should it be set below the level that would optimally address air pollution externalities?

Second, the distortionary cost of income taxation is disregarded even though the pertinent public policies affect the government's revenue needs. If, however, public goods implicitly carry an additional price because they must be financed via distortionary taxation, should the public sector be scaled back relative to what is indicated by the standard cost-benefit test? Similarly, should environmental taxes be set higher than necessary to internalize externalities because they produce a "double dividend," not only correcting externalities but also raising revenue and thus reducing the need to rely on distortionary income taxation?

My thesis in this essay is that the two asserted difficulties do not have the commonly assumed implications. Instead, economists' traditional principles

- Louis Kaplow is Finn M.W. Caspersen and Household International Professor of Law and Economics, Harvard Law School, and Research Associate, National Bureau of Economic Research, both in Cambridge, Massachusetts. 
provide the most useful benchmark for policy analysis. In justifying this claim, I will suggest that it is most helpful to contemplate policy experiments-consisting of underlying policies like provision of public goods combined with income tax adjustments—that are distribution neutral overall. As will be seen, this formulation not only renders distributive concerns moot, but also, in standard cases, implies that there will be no effects on labor supply either. This approach is introduced through simple examples followed by a more general statement, discussions of qualifications and connections to classical and contemporary literature, and suggestions for analysts and policymakers.

\section{Offsetting Tax Adjustments: Some Examples}

Public goods must be financed, and environmental taxes and subsidies need to be accompanied by some other fiscal adjustment if budget balance is to remain unaffected. Yet there are myriad ways in which budget balance may be achieved even if one confines attention, as is common in the literature, to modifications of the income tax system (taken here, following custom in such work, as a composite of income, sales, and payroll taxes as well as all manner of transfer programs). Furthermore, different income tax adjustments entail different consequences for the distribution of income and for labor supply. Compare, for example, raising a given amount of revenue by increasing tax rates on the rich versus adding a fixed dollar amount to everyone's tax bill. The former may be superior on distributive grounds, but also more distortionary.

What adjustment to the income tax system should analysts consider? First, consistency has virtues; otherwise, similar analyses of otherwise identical policies could reach widely different conclusions due entirely to disparities in ad hoc assumptions about how the policies will be financed. Second, of the many (consistent) ways that one could adjust the income tax system to achieve budget balance, ideally the intrinsic features of providing a public good or correcting an externality would not become entangled with concerns about the proper extent of income redistribution. Therefore, a distribution-neutral approach to policy analysis is warranted.

Accordingly, in each example that follows, a benefit-offsetting income tax adjustment will be constructed: a tax adjustment that, combined with the policy itself, is distribution neutral. As it turns out, this combination of policy and finance mechanism leaves labor supply unaffected. Since both distribution and labor supply remain unchanged, traditional principles like the cost-benefit test will provide proper guidance.

\section{Public Good with Uniform Benefits}

Consider a public good that provides uniform dollar benefits to everyone, say $\$ 100$ per capita. A benefit-offsetting tax adjustment is one that charges each individual $\$ 100$. The result of the package of public good and finance is obviously 
distribution neutral. It also (absent subtle complications, discussed below) does not affect labor supply because the benefit and the tax adjustment are offsetting and, in addition, each is a fixed amount that is independent of income and thus labor effort.

Suppose further that the cost of this public good is only $\$ 90$ per capita, in which case the simple cost-benefit test is passed. Because there would be a budget surplus if everyone's taxes were raised by $\$ 100$, the tax adjustment could be limited to $\$ 90$, in which case everyone would be better off. Conversely, if the cost exceeds the benefit, the tax adjustment would have to be greater than $\$ 100$, and all would be worse off. The simple cost-benefit test thus correctly indicates whether it makes sense to provide this public good given that finance will be through a benefitoffsetting tax adjustment.

Might this method of finance be deemed objectionable because it is tantamount to a lump-sum tax? Not really. First, a uniform lump-sum tax-more precisely, a uniform adjustment to the tax and transfer system-is quite feasible (unlike imagined lump-sum taxes that would vary with unobservable characteristics like individuals' abilities). Second, the familiar distributive objection to the wholesale use of lump-sum taxes is inapplicable here. A uniform upward adjustment in tax obligations is to be imposed to finance a public good that itself produces a uniform per capita benefit. If everyone pays an additional $\$ 90$ to receive a benefit that each values at $\$ 100$, there is a Pareto improvement involving an equal gain for all. The situation is not materially different from one in which a private good that costs $\$ 90$ to produce is sold on a competitive market for $\$ 90$ to individuals of various income levels who each value one unit of the good at $\$ 100$. Distributive objections are inapposite.

Might one instead complain that the example is unrealistic, in that much government activity benefits higher-income individuals more than the poor, in which case such finance would result in a package that is regressive overall? Yes, this example is atypical, which is why we will now consider examples in which the distributive incidence differs. Interestingly, however, these examples will make clear that uniform (lump-sum) finance really has nothing fundamental to do with the distribution-neutral approach, except by coincidence, as in this first example.

\section{Public Good with Benefits Proportional to Income}

To address the possibility that benefits from government projects may vary with income, consider now a case in which a public good produces benefits that rise in proportion to income. ${ }^{1}$ For example, suppose that a major expansion of the police force would be valued by all individuals at 1 percent of income, perhaps because those with higher incomes receive more direct benefit on account of their possessing more valuable goods that would be better protected against theft.

For a public good that produces a benefit valued by everyone at 1 percent of

\footnotetext{
${ }^{1}$ To be precise, after-tax (disposable) income is the relevant concept in the present example; this qualifier is omitted throughout for expositional convenience.
} 
income, the benefit-offsetting tax adjustment is that everyone pays an additional 1 percent of income in taxes (or has transfers reduced accordingly). At this point, the analysis proceeds as in the foregoing example. If (and only if) the benefits of expanding the police force exceed the costs, there will be a budget surplus. Although the form of the tax adjustment is quite different in this example, it remains the case that the benefit-offsetting tax adjustment, true to its name, raises revenue equal to the dollar sum of everyone's benefits. Thus, when benefits exceed costs, tax collections exceed expenditures. Accordingly, a smaller tax increase is sufficient to balance the budget, and everyone can be made better off. Once again, by construction we have a distribution-neutral outcome, so no adjustment to the cost-benefit test is warranted on account of distributive concerns.

But what about labor supply? Won't work be discouraged-beyond the distortion caused by the preexisting income tax-because 1 percent is added to everyone's tax obligations? The answer for the basic case (again, qualifications are noted below) is no: Any labor supply effect of the tax increase will be just offset by the labor supply effect of the public good. This point deserves some elaboration.

Suppose that an individual contemplates working harder by just enough to earn an additional $\$ 100$. Compared to the original regime-without the public good worth 1 percent of income and without the 1 percent tax adjustment-the individual will keep $\$ 1$ less on account of the reform package. However, by assumption it is also true that the utility value of the additional earnings, translated into dollars, is $\$ 1$ greater on account of the reform package. Indeed, this is what it means to say that the value of the benefit equals 1 percent of income. Put concretely, increasing one's earnings is more valuable than before because it is less likely that one will lose to theft the fruits of one's additional efforts. Combining this project benefit with the effect of the benefit-offsetting tax adjustment, an individual's net utility gain or loss from working harder is precisely the same after the reform as it was beforehand.?.$^{2}$ As a consequence, labor supply is unaffected. Since, as noted, the overall reform package is also distribution neutral, the simple costbenefit test is sufficient for our assessment.

\section{Gasoline Tax Increase with Incidence and Benefits that Vary with Income}

To appreciate the generality of the proposed approach, it is useful to consider one final example that examines the control of externalities rather than a public good and that incorporates a number of additional variations. Some government policies, like environmental taxes, directly raise revenue and in ways that may affect distribution and labor supply. Many policies, including most government regula-

\footnotetext{
${ }^{2}$ The analysis is more subtle when the reason that the value of a public good rises with income is the declining marginal utility of consumption. For example, if utility is additively separable in public goods, private goods, and labor, this will be the only reason value would rise with income. For analysis of this case, see Kaplow (1996, appendix, second example). Though the particulars differ from the case in the text, the conclusion is the same, a point that should be reinforced by the discussion and diagram accompanying the next example.
} 
tions, impose private compliance costs. Furthermore, benefits may have any relationship with income, not just being constant in dollars or strictly proportional to income as in the preceding two examples.

To illustrate how the present approach can take all such complications into account, consider an increase in the gasoline tax motivated by a desire to internalize externalities such as pollution and perhaps traffic congestion. This example is depicted in Figure 1. The gasoline tax increase itself is assumed to be regressive, with an incidence that rises, although less than proportionately, with income. This relationship is shown by the dotted curve, which is drawn below the horizontal axis because tax payments constitute a loss to individuals.

The gasoline tax increase is also assumed to affect gasoline consumption. Individuals may drive less, purchase different vehicles, and so forth. These behavioral responses entail financial costs and forgone utility to individuals, but also produce benefits, here assumed to be reduced pollution and less congestion. As the dashed curve indicates, this net effect, "project benefits - nontax costs" (ignoring the gasoline tax payments themselves), is assumed to be positive and rising with income at an increasing rate. That is, these net project benefits are hypothesized to be worth disproportionately more to the rich, perhaps because clean air and saved time are much more valuable to them.

The solid curve shows that the net impact of the project-consisting of the gasoline tax payments combined with these project benefits and nontax costs-is a moderate net loss to lower-income individuals and a rising net gain to higherincome individuals.

The offsetting (and in this case nonlinear) adjustment to the income tax schedule in this case can be determined straightaway. It is the same solid net impact curve, except that it must be interpreted as a payout rather than a receipt (hence the negative sign in the label on Figure 1). After all, the tax schedule adjustment is constructed to offset, at each level of income, the net benefits of the project. It follows immediately that no distributive concern is raised either by the fact that the gasoline tax increase is, in itself, regressive or by the fact that the net benefits of the gasoline tax disproportionately favor the rich. The offsetting tax adjustment washes away these distributive effects.

Moreover, it is again the case that there is no overall effect on labor supply. To be sure, the gasoline tax increase in isolation may well have reduced labor supply because those who earn more pay more on this account. Conversely, the net benefits (project benefits - nontax costs) in isolation may have increased labor supply because they are rising with income and thus make the prospect of increased earnings more attractive. Why is it that the net effect of all these components on labor supply must be nil at every level of income?

The answer arises from the very nature of the construct of a benefit-offsetting income tax adjustment. We can determine the net effect of all aspects of the gasoline tax increase combined with the income tax adjustment from Figure 1. Subtract the solid curve, representing the income tax adjustment, from itself, this time representing the net impact of the gasoline tax increase. Obviously, the result 
Figure 1

Gasoline Tax Increase and Offsetting Income Tax Adjustment

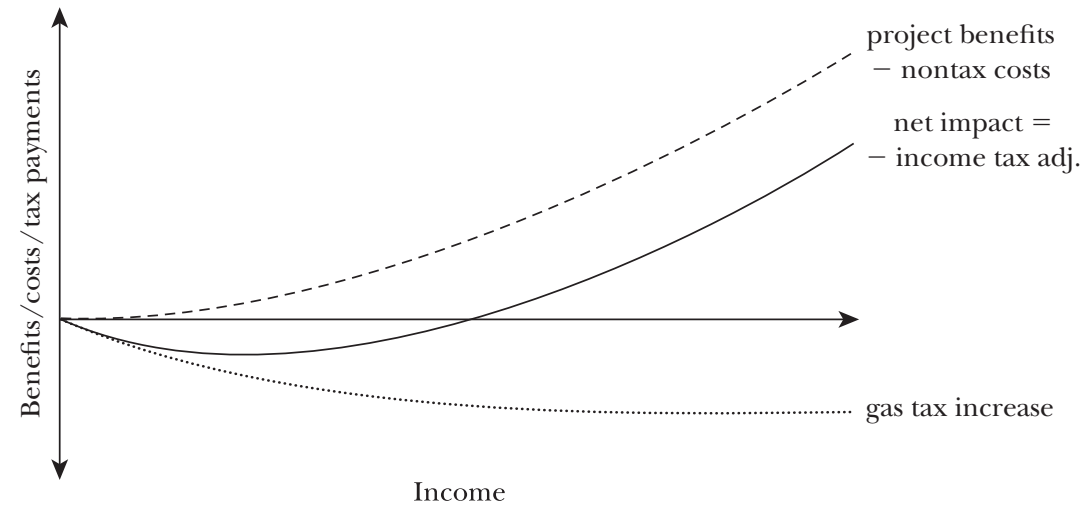

is zero impact, and, just as obviously, this is no coincidence. At every possible level of income that an individual may earn, the individual's utility without the reform is identical to the individual's utility in a world with the reform. Hence, whatever level of labor effort was best for the individual initially, that same level of labor effort will be optimal after enactment.

To complete the analysis, observe that the hypothesized offsetting adjustment to the income tax schedule will result in a budget surplus-allowing one to reduce everyone's taxes somewhat, making everyone better off-if and only if the gasoline tax increase is cost-beneficial by traditional measures. That is, if the gasoline tax moves in the direction of internalizing an externality, all stand to gain from its implementation, financed in a manner that is overall distribution neutral. This is true because, at each income level, the benefit-offsetting tax adjustment equals the direct benefits minus compliance costs and gasoline tax payments. Hence, summing across the population, the net budgetary impact (before the rebate) will simply equal the difference between total benefits and total costs, just as in the prior two examples.

In sum, the reform package as a whole is distribution neutral, has no effect on labor supply, and produces a budget surplus that can be rebated so as to benefit everyone if and only if the traditional policy test is satisfied.

\section{Elaboration and Qualifications}

\section{The General Claim and Its Underlying Intuition}

With these three examples in mind, it is useful to state the general claim more precisely and to elaborate on the intuition that underlies it, particularly with regard 
to the point that labor supply is unaffected when a government project is financed using a benefit-offsetting income tax adjustment. . $^{\text {a }}$

To begin, the benefit-offsetting tax adjustment is a modification to the entire income tax (and transfer) schedule. At each income level, the increase or reduction in the amount of tax owed is defined to be that amount that individuals would have to pay or receive such that their utility with the government project and the income tax adjustment is the same as their utility without either one. Stated more precisely, let $u(l)$ denote an individual's reduced-form utility as a function of labor supply in the initial regime and $u^{\circ}(l)$ denote the individual's utility function in the regime with the government project (but no tax adjustment). To maintain common units, it is convenient to express the benefit-offsetting tax adjustment in utility rather than dollars. Therefore, we have $t(l)=u^{\circ}(l)-u(l)$, where $t(l)$ indicates the amount by which utility is reduced by the tax adjustment at each level of labor supply. (That the same tax adjustment works for all individuals, regardless of earning ability, depends on homogeneity of preferences and what is referred to as weak leisure separability, as will be explained below when discussing qualifications.)

Given this construction of the offsetting income tax adjustment, the reform combined with the tax adjustment will affect neither labor supply nor distribution. An individual's utility after the reform (including the tax adjustment) is simply $u^{\circ}(l)-t(l)$, which by construction of $t(l)$ just equals $u(l)$, utility before the reform. Thus, whatever level of labor supply maximized utility initially must also be the level of labor supply that maximizes utility with the reform and the tax adjustment. Moreover, because everyone's utility is the same as before, distribution is also unaffected.

Accordingly, the reform-whether a change in the level of a public good, correction of an externality, or any other government activity-will make sense if and only if the government is left with a budget surplus, which can be rebated to the population. Furthermore, as discussed in the three examples, whether a surplus is generated is determined exactly by a standard cost-benefit test. After all, the offsetting tax adjustment is defined to soak up each individual's net benefits from the reform. Thus, if the sum of everyone's net benefits is positive, revenue is positive.

At this point, it should be clear that the logic of the argument does not depend on the type of government reform, the distributive incidence of any costs or benefits, or any particular assumptions about the distortionary nature of labor income taxation. The reason is that everything-except the net benefits of the reform itself-is held constant using the offsetting tax adjustment. ${ }^{\mathbb{4}}$ The intuition

\footnotetext{
${ }^{3}$ For a formal analysis of the general case and some worked-out special cases, see the appendix in Kaplow (1996). Subsequent formal analysis also appears in Auerbach and Hines (2002) and Kaplow (2003).

${ }^{4}$ The only exception under present assumptions is that the further step of rebating the surplus will tend to reduce labor supply and thus revenue. The only implication is that the actual budget-balancing rebate will be less than the full per capita amount of the original budget surplus.
} 
behind this conclusion is reinforced by considering that the proposed benefitoffsetting tax adjustment is a sort of "benefit taxation" (Kaplow, 1996, 2003). Because whatever individuals pay is equal to the value of what they receive, and this relationship holds at every level of earnings, it should not be surprising that labor supply will be unaffected.

\section{Qualifications}

Is it always true that basic principles, like the Samuelson cost-benefit test for public goods and the Pigouvian prescription for internalizing externalities, provide precisely the correct policy prescriptions when finance is distribution neutral? The answer, unsurprisingly, is: Of course not. The world is never so simple. It is useful to explore the most important qualifications, both to appreciate the limitations of the foregoing analysis and to reinforce the intuition that underlies it. As will be seen, although many of the qualifications suggest that the basic rules may not be precisely right and sometimes may be significantly off, deviations are not systematically in any particular direction. Moreover, when modifications are appropriate in light of these qualifications, they tend to be different in kind from those called for by the conventional concerns about distribution and labor supply distortion that were mentioned at the outset.

One qualification concerns the possibility that government projects may affect labor supply indirectly. (This possibility was ruled out above in the passing reference to the assumption of weak leisure separability. $)^{6}$ Consider a public good that consists of improved national parks and beaches or an environmental regulation whose primary effect is to increase the quality of such recreational destinations. These government actions make leisure more attractive, ceteris paribus, and thus induce individuals to reduce labor supply. Given that labor supply is already distorted downward by redistributive taxation, this effect is socially costly. As a consequence, it will tend to be optimal on second-best grounds to supply somewhat less of these public goods and to control such externalities less than otherwise. Conversely, public goods and environmental regulations that enhance the ambience of central cities may increase labor supply because they increase the utility associated with work. Accordingly, such public goods and environmental regulations would optimally be provided at higher levels or set more stringently than otherwise. Note that the direction of these modifications does not depend on the distributive incidence of the government project (which will be offset by the tax

\footnotetext{
${ }^{5}$ Pertinent literatures, notably on optimal income taxation, have identified other subtle qualifications such as interactions with income-earning ability, which is assumed to be unobservable (for example, Mirrlees, 1976).

${ }^{6}$ Formally, weak leisure separability means that if, say, utility is a function of vectors of private goods $x$, public goods $g$, and externalities $e$, as well as labor supply-that is, we have $u(x, g, e, l)$-it is possible to write the utility function in the form $u(v(x, g, e), l)$, where $v$ is a subutility function. Intuitively, this separability means that individuals' tradeoffs among private goods, public goods, and externalities are unaffected by the level of labor they choose to supply.
} 
adjustment) and does not reflect any simple preference for lower government spending or for policies that incidentally raise additional revenue.

A second caveat to the claim that standard policy prescriptions produce Pareto improvements is due to the heterogeneity of individuals' preferences (Boadway and Keen, 1993; Hylland and Zeckhauser, 1979; Kaplow, 1996). The benefit-offsetting tax adjustment at any income level may only reflect the average benefits to individuals at that income level. Thus, individuals with atypically strong tastes for the government project will gain, even accounting for the tax adjustment, and those with weaker tastes will lose. (This assumes that individuals' differences are unobservable, rendering customized tax adjustments infeasible.) For example, expenditures to improve parks will benefit those individuals who love the out-of-doors but provide little gain to those who prefer watching television. When financed with an offsetting tax adjustment equal to average gains, the former will be winners, but the latter may well be losers, even though the project passes the standard cost-benefit test. Although the presence of such heterogeneity usually makes Pareto improvements impossible, it does not have systematic implications regarding whether various policy tests should be more or less stringent. However, in particular situations, heterogeneity may bear on the desirability of government activity. For example, enhanced police protection may be relatively more beneficial to individuals who, even holding income constant, are overall worse off: those who are relatively weak or otherwise vulnerable. Given certain social preferences for equality, this factor may favor a higher level of provision than would otherwise be optimal. Nevertheless, the present concern about heterogeneity does not pertain to the overall distribution of income-which is held constant by the benefit-offsetting tax adjustment-but rather involves only disparities among individuals at the same income level. Likewise, this qualification does not relate in any direct way to the distortionary cost of redistributive taxation.

A third qualification takes account of certain costs of taxation itself, other than labor supply distortion, as discussed in $\mathrm{Ng}$ (2000) and Slemrod and Yitzhaki (2001). There are administrative and compliance costs associated with tax collections and problems of evasion. These frictions do imply that there is a marginal cost of public funds, although not on the order of magnitude of labor supply distortion. 7 These outlays are directly analogous to costs that arise with market provision of private goods, such as the expense of collecting payment and losses due to shoplifting. In addition, actual tax systems discriminate among various activities. Different assets may be taxed at differential rates, tax preferences exist for certain fringe benefits, and other discrepancies abound. These imperfections further contribute to the cost of raising revenue. (The implication of such costs is not unambiguous; for example, when budgets are tight, the need for additional funds sometimes leads to

\footnotetext{
${ }^{7}$ This conclusion is especially true in light of the fact that distortion tends to rise disproportionately with (in simple cases, with the square of) the marginal tax rate, which for labor income (including income, payroll, and consumption taxes) is usually estimated for the United States to be just over 40 percent.
} 
the closing of loopholes, thereby reducing these secondary distortions.) However, as with the first two qualifications, such complications do not relate directly either to the distributive incidence of the public project in question or to the distortion of labor supply.

These three qualifications and others that could be adduced indicate, as one would expect, that simple principles like the cost-benefit test are not literally correct and sometimes may need significant modification. Note that, for the most part, the necessary adjustments may go in either direction, and they are not determined in any simple manner by the two worries with which we began, concerning distribution and labor supply distortion.

\section{History of Thought on Distribution and Labor Supply Distortion}

\section{Classic Statements}

Scholarship on rules of policy analysis-which has focused on public goods and externalities, along with worries about distribution and labor supply distortion-can usefully be clustered into three overlapping waves. The first consists of classic statements of fundamental principles.

The cost-benefit test for public goods is due to Samuelson's (1954) elegant articulation half a century ago in "The Pure Theory of Public Expenditure," in which he showed that optimality involves equating the sum of individuals' marginal benefits to the marginal cost of provision. Interestingly for present purposes, Samuelson's formulation is explicitly in a first-best setting in which individualized lump-sum taxes in principle allow any social welfare optimum to be achieved, without labor supply distortion.

The command to internalize externalities is inspired by Pigou's (1920) classic, The Economics of Welfare. His exposition is notable both for his diagnosis of the problem of divergences between private and social costs and benefits and for his suggesting the use of taxes and subsidies as a possible cure. In the case of negative externalities, the prescription is to impose a tax equal to the marginal external harm.

Musgrave's (1959) pioneering treatise, The Theory of Public Finance, suggests an analytical division between efficiency and distribution issues. He advances the view that government can be understood as divided into imaginary branches, including an Allocation Branch that focuses on maximizing efficiency by providing public goods and controlling externalities and a Distribution Branch that specializes in addressing distributive concerns. If such a separation is entirely valid, it suggests that first-best principles should guide decisions about government projects while concerns about distribution should be in the exclusive province of those tasked to redistribute income.

\section{Revisionist Accounts}

A second wave of literature, which continues to the present day, advances reservations regarding income distribution and labor supply distortion. Thus, 
Weisbrod (1968), Drèze and Stern (1987), and others emphasize the need to employ distributive weights in cost-benefit analysis to account for the distributive incidence of public projects. In regulating externalities, distributive apprehensions are widespread; as one example, Casler and Rafiqui (1993) examine distributive concerns related to fuel taxes.

Regarding distortion, concerns were raised with respect to the cost of providing public goods at least as early as another of Pigou's (1928) classics, A Study in Public Finance. Work on the subject accelerated in the early 1970 s as part of the explosion of interest in optimal taxation (Atkinson and Stern, 1974; Diamond and Mirrlees, 1971; Stiglitz and Dasgupta, 1971; subsequent research was elucidated in this journal in Ballard and Fullerton, 1992). More recently, economists have examined whether various regulatory schemes might produce a "double dividend"; that is, an environmental tax might both correct an externality and also raise additional revenue without distorting labor supply (Ballard and Medema, 1993; Cordes, Nicholson and Sammartino, 1990). Subsequent investigations indicate that a double dividend may be unlikely, suggesting instead that environmental regulation tends to exacerbate the preexisting distortion of labor supply (Bovenberg and Goulder, 2002; Goulder, 2002).

The second-wave literature pursues a plausible agenda of determining how simple rules of policy analysis should be modified to account for policies' distributive effects and for labor supply distortion associated with income taxation. Unfortunately, the results are often incomplete and misleading, primarily for two reasons.

The first problem concerns which income tax adjustments are assumed to be used to finance public goods or accompany the regulation of externalities. In some instances, such as in the aforementioned literature on the use of distributive weights in cost-benefit analysis, no tax adjustment is specified, in which case analysis is confined to an implicitly incomplete policy that consists of the government project with financing left in the air. More often, the income tax is adjusted to balance the budget, but the tax adjustment chosen varies from one study to another and, in any event, is more or less arbitrary. When the tax adjustment is not a distributively offsetting one, however, any result concerning labor supply is possible, depending on whether the project combined with the hypothesized tax adjustment increases or reduces redistribution.

Significant portions of the work on public goods and environmental regulation tend to find adverse effects on labor supply, and this-it should now be no surprise-reflects the implicit use of tax adjustments that increase redistribution. With public goods, a study might report, say, a marginal cost of public funds of $\$ 1.45$ rather than $\$ 1.00$. This cost can arise, for example, by combining a project that produces uniform dollar benefits with a tax adjustment consisting of an increase in everyone's marginal income tax rate, such as in one of the cases considered by Ballard and Fullerton (1992) and others in which the public good is assumed to be a substitute for private consumption. Obviously, this package is more redistributive. With environmental regulation, some literature, for example, on 
pollution quotas (surveyed in Bovenberg and Goulder, 2002) compares otherwise equivalent regulatory regimes that have different revenue consequences, where budget balance is achieved by changing marginal income tax rates. In such cases, the environmental regimes that raise more revenue are less distortionary; however, because the distortion reduction is a consequence of reduced reliance on income taxation, these regimes are also less redistributive. Other literature on public goods and regulation in essence utilizes tax adjustments that have an incidence proportional to income whereas hypothesized benefits rise with income less than proportionally, as a consequence of subtle modeling assumptions. ${ }^{8}$ The result is that greater public goods provision or environmental protection adversely affects labor supply because it implicitly is more redistributive.

The second problem is that much work on the marginal cost of public funds (surveyed in Ballard and Fullerton, 1992) and on environmental regulation (for example, numerical assessments of green tax reforms, surveyed in Bovenberg and Goulder, 2002) considers efficiency but ignores redistribution. This selective focus is particularly worrisome precisely because, as just explained, the overall package of policy reform and income tax adjustment that is analyzed in second-wave literature often entails increases in the extent of redistribution. The omission of redistributive benefits may nominally be justified by the fact that these studies frequently employ representative-individual models in which everyone is identical. However, the raison d'être of labor income taxation-the source of much distortion in this literature-is redistribution among nonidentical individuals. Hence, it is problematic to offer a welfare assessment that depends heavily on how changes in the level of such taxation affect labor supply when the setting involves redistributive effects running in the opposite direction that are artificially assumed to be inconsequential.

These two shortcomings in the second-wave literature's attempt to address distribution and labor supply distortion motivate further inquiry. It is necessary to

\footnotetext{
${ }^{8}$ As Ballard and Fullerton (1992) explain, if the public project is independent of labor supply, the marginal cost of public funds will exceed one when the uncompensated labor supply curve is upward sloping, as is often assumed. However, taking the simple case of additive separability of private consumption, public benefit (public good or environmental protection) and labor, this condition for an adverse effect on labor supply is a sufficient condition for an increase in redistribution. (The intuition is that the condition requires that the income effect not be too great, meaning that the marginal utility of consumption does not fall very rapidly, which directly implies that the marginal value of the public benefit does not rise sharply as a function of income.) Another subtle source of increased redistribution appears in studies of environmental regulation that hold the value of income transfers constant in real terms (for example, Goulder, Parry, Williams and Burtraw, 1999). In this case, the poorest individuals are made whole with regard to private goods and net taxes through the stipulated adjustments to the tax-transfer system, and they furthermore benefit as environmental protection rises; the rich, through steeper marginal income tax rates, in essence pay for both their own environmental benefits and a share of others' benefits. These sorts of phenomena are not readily apparent because most of this work does not report the distributive incidence of environmental benefits or of regulatory and tax costs. Additional examples are presented by Allgood and Snow (1998), who show that a substantial portion of differences in leading empirical estimates of the marginal cost of funds and of redistribution can be attributable to subtle ways in which different authors' simulations implicitly change the level of effective lump-sum transfers and thus the extent of redistribution assumed to take place.
} 
think seriously about how best to match income tax adjustments to public projects. Furthermore, it is important to integrate analysis of distribution and labor supply distortion rather than treating the issues separately. These two demands motivate the present analysis, which draws on another set of contributions.

\section{New View}

A third wave of work on rules of policy analysis, which might be characterized as offering a "new view" on distribution and labor supply distortion, has gradually emerged. Hylland and Zeckhauser (1979), in an important but underappreciated article, use the device of benefit-offsetting tax adjustments to show that distributive weights are unnecessary in cost-benefit analysis. Shavell (1981) employs a similar construct to demonstrate that legal rules should be assessed without regard to their distributive effects. Technical papers by Christiansen (1981) and Boadway and Keen (1993) show that in basic cases, if income taxes are set optimally, the simple cost-benefit test for public goods provision provides proper guidance. This latter work takes advantage of the fact that, when at the optimum, the marginal benefit of additional redistribution equals the marginal cost of additional labor supply distortion, so marginal adjustments to the tax system have no net effect on social welfare. Kaplow (1996) advances the broader view that worries about both distribution and labor supply distortion tend to be misconceived with regard to a wide domain of government policy, notably including regulation as well as public goods, using the approach of offsetting tax adjustments that does not depend on the income tax system being at an optimum. Subsequent related work includes $\mathrm{Ng}$ (2000) and Slemrod and Yitzhaki (2001).

The teachings of the new view can also be analogized to earlier work on when it is optimal to employ differential commodity taxation when an income tax is also available. Specifically, Atkinson and Stiglitz (1976) show that it is optimal to tax or subsidize a private good (relative to a baseline of uniform treatment) only to the extent that it is, respectively, a complement of or substitute for leisure. ${ }^{9}$ (The intuition for their result parallels the above explanation of why it is optimal, say, to provide more or less of a public good than indicated by the standard cost-benefit test, depending on the relationship between the public good and preferences for leisure.) That is, in the basic case, the simple rule that commodities should be taxed uniformly is correct, even in a setting in which distribution matters and income taxation distorts labor supply. The present analysis of a range of government policies can be seen as a sort of corollary to this important result of Atkinson and Stiglitz by observing, for example, that providing less of a public good or setting a

\footnotetext{
${ }^{9}$ Mirrlees (1976) and Konishi (1995) note the connection between public goods provision and optimal commodity taxation, and Kaplow (1996) discusses the implications more broadly. Atkinson and Stiglitz's (1976) demonstration makes use of the optimality of the income tax. Kaplow (2004) extends the result to any income tax, using a benefit-offsetting tax adjustment instead of relying on properties of the optimum.
} 
Pigouvian tax above the level of the externality is analogous to taxing an ordinary private good relative to other goods. $\frac{10}{}$

\section{The Virtues of Distribution-Neutral Policy Analysis}

The framework advanced in this essay employs benefit-offsetting income tax adjustments that render moot familiar concerns about distribution and labor supply distortion. But what if some other tax adjustment might be utilized? In that case, analysts might wish to examine the tax adjustment actually specified in a current proposal. However, the tax adjustment may not be specified at all, it may vary across proposals, or it may change. Specification may also be meaningless because the tax adjustment being proposed (say, closing a particular tax loophole) is likely to be one with sufficient legislative support that it would be used to finance a subsequent proposal if the current one is not enacted. In addition, as time passes, both projects and methods of finance will each evolve in their own directions. If one had to speculate about how redistribution would ultimately tend to be affected by government projects, it seems plausible to suppose, as a first approximation, that the long-run political equilibrium regarding redistribution will not be affected in an obvious, predictable manner by this or that government action, which would justify an assumption of distribution-neutral finance as the baseline for analysis.

There should in any event be a standard method of analyzing policy packages that separates the intrinsic merits of the policy from matters of redistribution. As suggested in Kaplow (1996), it is useful to imagine that any proposed policy and associated income tax adjustment is implemented in two steps: 1) the policy financed by a benefit-offsetting (distribution-neutral) income tax adjustment, as described throughout this essay; 2) a purely redistributive income tax adjustment, that is, a reform under which the hypothetical benefit-offsetting tax adjustment from step 1 is replaced by the actual tax adjustment. This decomposition yields substantial gains from specialization. Those most knowledgeable about environmental regulation, health care, education policy, and so forth can focus their efforts on step 1, examining factors peculiar to those subjects when applying standard cost-benefit tests. Others can study step 2, concerned purely with income redistribution, by refining models of redistributive taxation, obtaining better estimates of the labor supply elasticity and the distribution of earning abilities, and addressing the question of the appropriate social welfare function; the results of such studies can be applied generically, to all manner of government action.

Without such a two-step decomposition, the outcome of any particular study,

\footnotetext{
${ }^{10}$ Readers familiar with principles of Ramsey taxation-the inverse elasticity rule on efficiency grounds and the preference for higher taxes on luxuries and lower taxes on necessities on distributive groundsmay find such dictates contradicted by the explanation in the text. This is indeed the case. As Atkinson and Stiglitz (1976) explain, Ramsey results and applications based thereon must be largely cast aside if the instrument of an income tax is available. See also Stiglitz (1987).
} 
say, of a gasoline tax increase, will depend on a mixture of the following: 1) the analysis and empirical estimates pertinent to the gasoline tax increase per se; 2) what particular tax adjustment is postulated; 3) the analysis and empirical estimates pertinent to redistributive taxation; and 4) the choice of social welfare function to aggregate all effects. When these elements are entangled, the task of interpreting a single study or comparing studies that disagree will be quite difficult even for specialists and probably impossible for less technically sophisticated policymakers. This problem is compounded when results are produced using complex general equilibrium simulation models where numerous details pertaining to all of the four categories must be absorbed to comprehend how each issue is being addressed. With the proposed two-step decomposition, differences in conclusions of studies of gasoline tax increases would then all be attributable to category 1 ; the resulting enhancement of conceptual clarity should greatly facilitate progress in research as well as understanding by outsiders.

There are also practical virtues of the proposed approach. The most obvious benefit is that the two steps of the decomposition not only are distinguishable conceptually but also can be separated in practice. For example, when the first step of a composite reform-the government action in itself-is desirable and the second-the redistributive change-is unwanted, only the first step need be adopted; a policymaker would not, however, know when this is the case if policy analysts present results only for the composite package. In addition, separate identification of redistributive effects and their associated labor supply distortion helps to keep policymakers from being misled, as such may result from many current studies that examine only distribution or only labor supply distortion. For example, more labor supply distortion, naturally presented as an evil in much of the second-wave literature, is symptomatic of greater redistribution-a net good to those who favor additional redistribution and a partially offsetting good even to many who favor less. Likewise, adjusting simple policy tests solely for redistributive effects is misleading in the opposite direction.

If one is optimistic, or perhaps naive, one might hope that clear presentation of the results from distribution-neutral policy analysis would improve government decision-making by reducing the extent to which general distributive politics interfere with the ability to implement socially beneficial policies. If distributionneutral analysis reveals a policy to be efficient, enactment-specifically of the distribution-neutral package-may be more likely to be feasible because, as explained, all income groups will be winners. Likewise, when a policy is inefficient, all groups would be losers, rendering enactment more difficult. Of course, the political process is far more complicated than this, and, as previously noted, there exists heterogeneity among individuals that is unrelated to differences in income levels. Nevertheless, if economic policy analysts consistently present results for distribution-neutral policy combinations, which clearly identify which proposals are efficient and which are not, perhaps this would enhance the quality of public decision-making.

Whether or not policies will be financed in a manner that is overall distribution 
neutral, it remains the case that the proposed approach to policy analysis has many virtues, conceptual and practical, that favor its widespread use by economists as a benchmark for policy analysis. It would clarify existing thinking and teaching. It would facilitate the analysis of underlying government policies, like provision of particular types of public goods and enactment of various environmental regulations. It would sharpen our understanding of redistributive, distortionary labor income taxation. Finally, the proposed approach would enhance policymakers' ability to digest economic policy analysis and thus may improve the quality of economic policy.

- The author is grateful to Alan Auerbach, James Hines, Steven Shavell, Andrei Shleifer, Timothy Taylor, Michael Waldman, David Weisbach, and workshop participants for comments, Amy Sheridan for research assistance, and the John M. Olin Center for Law, Economics, and Business at Harvard University for financial support. The issues explored here are developed in greater depth in Taxation and Redistribution, a book in progress.

\section{References}

Allgood, Sam and Arthur Snow. 1998. "The Marginal Cost of Raising Tax Revenue and Redistributing Income." Journal of Political Economy. 106:6, pp. 1246-73.

Atkinson, Anthony B. and Nicholas H. Stern. 1974. "Pigou, Taxation, and Public Goods." Review of Economic Studies. 41:1, pp. 119-28.

Atkinson, Anthony B. and Joseph E. Stiglitz. 1976. "The Design of Tax Structure: Direct Versus Indirect Taxation." Journal of Public Economics. 6:1-2, pp. 55-75.

Auerbach, Alan J. and James R. Hines Jr. 2002. "Taxation and Economic Efficiency," in Handbook of Public Economics, Volume 3. Alan J. Auerbach and Martin Feldstein, eds. Amsterdam: Elsevier, pp. 1347-421.

Ballard, Charles L. and Don Fullerton. 1992. "Distortionary Taxes and the Provision of Public Goods." Journal of Economic Perspectives. 6:3, pp. 117-31.

Ballard, Charles L. and Steven G. Medema. 1993. "The Marginal Efficiency Effects of Taxes and Subsidies in the Presence of Externalities: A Computational General Equilibrium Approach." Journal of Public Economics. 52:2, pp. 199-216.

Boadway, Robin and Michael Keen. 1993. "Public Goods, Self-Selection and Optimal In- come Taxation." International Economic Review. 34:3, pp. 463-78.

Bovenberg, A. Lans and Lawrence H. Goulder. 2002. "Environmental Taxation and Regulation," in Handbook of Public Economics, Volume 3. Alan J. Auerbach and Martin Feldstein, eds. Amsterdam: Elsevier, pp. 1471-545.

Casler, Stephen D. and Aisha Rafiqui. 1993. "Evaluating Fuel Tax Equity: Direct and Indirect Distributional Effects." National Tax Journal. 46:2, pp. 197-205.

Christiansen, Vidar. 1981. "Evaluation of Public Projects under Optimal Taxation.” Review of Economic Studies. 48:3, pp. 447-57.

Cordes, Joseph J., Eric M. Nicholson and Frank J. Sammartino. 1990. "Raising Revenue by Taxing Activities with Social Costs." National Tax Journal. 43:3, pp. 343-56.

Diamond, Peter A. and James A. Mirrlees. 1971. "Optimal Taxation and Public Production II: Tax Rules.” American Economic Review. 61:3, pp. 261-78.

Drèze, Jean and Nicholas Stern. 1987. "The Theory of Cost-Benefit Analysis," in Handbook of Public Economics, Volume 2. Alan J. Auerbach and Martin Feldstein, eds. Amsterdam: NorthHolland, pp. 909-89. 
Goulder, Lawrence H. 2002. Environmental Policy Making in Economies with Prior Tax Distortions. Cheltenham, UK: Edward Elgar.

Goulder, Lawrence H., Ian W. H. Parry, Roberton C. Williams III, and Dallas Burtraw. 1999. "The Cost-Effectiveness of Alternative Instruments for Environmental Protection in a Second-Best Setting." Journal of Public Economics. 72:3, pp. 329-60.

Hylland, Aanund and Richard Zeckhauser. 1979. "Distributional Objectives Should Affect Taxes But Not Program Choice or Design." Scandinavian Journal of Economics. 81:2, pp. 264-84.

Kaplow, Louis. 1996. "The Optimal Supply of Public Goods and the Distortionary Cost of Taxation." National Tax Journal. 49:4, pp. 513-33.

Kaplow, Louis. 2003. "Public Goods and the Distribution of Income." NBER Working Paper No. 9842.

Kaplow, Louis. 2004. "On the Undesirability of Commodity Taxation Even When Income Taxation is Not Optimal." NBER Working Paper No. 10407.

Konishi, Hideo. 1995. "A Pareto-Improving Commodity Tax Reform under a Smooth Nonlinear Income Tax." Journal of Public Economics. 56:3, pp. 413-46.

Mirrlees, James A. 1976. "Optimal Tax Theory: A Synthesis.” Journal of Public Economics. 6:4, pp. 327-58.

Musgrave, Richard A. 1959. The Theory of Public Finance. New York: McGraw-Hill.

Ng, Yew-Kwang. 2000. "The Optimal Size of Public Spending and the Distortionary Cost of
Taxation.” National Tax Journal. 53:2, pp. 25372.

Pigou, A. C. 1920. The Economics of Welfare. London: Macmillan.

Pigou, A. C. 1928. A Study in Public Finance. London: Macmillan.

Samuelson, Paul. 1954. "The Pure Theory of Public Expenditure." Review of Economics and Statistics. 36:4, pp. 387-89.

Shavell, Steven. 1981. "A Note on Efficiency vs. Distributional Equity in Legal Rulemaking: Should Distributional Equity Matter Given Optimal Income Taxation?" American Economic Review. 71:2, pp. 414-18.

Slemrod, Joel and Shlomo Yitzhaki. 2001. "Integrating Expenditure and Tax Decisions: The Marginal Cost of Funds and the Marginal Benefit of Projects." National Tax Journal. 54:2, pp. 189-201.

Stiglitz, Joseph E. 1987. "Pareto Efficient and Optimal Taxation and the New New Welfare Economics," in Handbook of Public Economics, Volume 2. Alan J. Auerbach and Martin Feldstein, eds. Amsterdam: North-Holland, pp. 991-1042.

Stiglitz, Joseph E. and Partha Dasgupta. 1971. "Differential Taxation, Public Goods, and Economic Efficiency." Review of Economic Studies. 38: 114, pp. 151-74.

Weisbrod, B. A. 1968. "Income Redistribution Effects and Cost-Benefit Analysis," in Problems in Public Expenditure Analysis. Samuel B. Chase, ed. Washington, D.C.: Brookings Institution, pp. 177-209. 


\section{This article has been cited by:}

1. Sonia Jaffe,, E. Glen Weyl. 2013. The First-Order Approach to Merger Analysis. American Economic Journal: Microeconomics 5:4, 188-218. [Abstract] [View PDF article] [PDF with links]

2. Paul Niehaus, Sandip Sukhtankar. 2013. The marginal rate of corruption in public programs: Evidence from India. Journal of Public Economics 104, 52-64. [CrossRef]

3. G.E. Metcalf, D. WeisbachCarbon Taxes 9-14. [CrossRef]

4. By Louis Kaplow. 2012. OPTIMAL CONTROL OF EXTERNALITIES IN THE PRESENCE OF INCOME TAXATION*. International Economic Review 53:2, 487-509. [CrossRef]

5. Claus Thustrup Kreiner, Nicolaj Verdelin. 2012. Optimal Provision of Public Goods: A Synthesis*. The Scandinavian Journal of Economics no-no. [CrossRef]

6. Louis Kaplow. 2011. An Optimal Tax System*. Fiscal Studies 32:3, 415-435. [CrossRef]

7. JAMES E. ANDERSON, WILL MARTIN. 2011. Costs of Taxation and Benefits of Public Goods with Multiple Taxes and Goods. Journal of Public Economic Theory 13:2, 289-309. [CrossRef]

8. Bruno De Borger. 2011. Optimal congestion taxes in a time allocation model. Transportation Research Part B: Methodological 45:1, 79-95. [CrossRef]

9. D FULLERTON, S KIM. 2008. Environmental investment and policy with distortionary taxes, and endogenous growth. Journal of Environmental Economics and Management 56:2, 141-154. [CrossRef]

10. W. MAX CORDEN, PETER FORSYTH, CHRISTIS G. TOMBAZOS. 2008. Distinguished Fellow of the Economic Society of Australia, 2007: Yew-Kwang Ng. Economic Record 84:265, 267-272. [CrossRef]

11. Udo Ebert, Georg Tillmann. 2007. Distribution-neutral provision of public goods. Social Choice and Welfare 29:1, 107-124. [CrossRef]

12. Ian W. H. Parry, Margaret Walls, Winston Harrington. 2007. Automobile Externalities and Policies. Journal of Economic Literature 45:2, 373-399. [Abstract] [View PDF article] [PDF with links]

13. Louis Kaplow, Carl ShapiroChapter 15 Antitrust 2, 1073-1225. [CrossRef]

14. Richard L. Revesz, Robert N. StavinsChapter 8 Environmental Law 1, 499-589. [CrossRef]

15. Louis KaplowChapter 10 Taxation 1, 647-755. [CrossRef] 